Marquette University

e-Publications@Marquette

College of Nursing Faculty Research and

Publications

Nursing, College of

6-1-2016

Educating Family Caregivers for Older Adults About Delirium: A Systematic Review

Margaret J. Bull

Marquette University, margaret.bull@marquette.edu

Lesley Boaz

Marquette University, lesley.boaz@marquette.edu

Martha G. Jermé

Marquette University, martha.jerme@marquette.edu

Accepted version. Worldviews on Evidence-Based Nursing, Vol. 13, No. 3 (June 2016): 232-240. DOI.

(C) 2016 Wiley. Used with permission. 


\title{
Educating Family Caregivers for Older Adults About Delirium: A Systematic Review
}

\author{
Margaret J. Bull \\ College of Nursing, Marquette University \\ Milwaukee, WI \\ Lesley Boaz \\ College of Nursing, Marquette University \\ Milwaukee, WI \\ Martha Jermé \\ Raynor Memorial Libraries, Marquette University \\ Milwaukee, WI
}

\section{ABSTRACT}

Background: Delirium in older adults is considered a medical emergency; it contributes to a cascade of functional decline and to increased mortality. Early recognition of delirium symptoms is critical to prevent these negative consequences. Family caregivers who are educated about delirium could partner with nurses and other healthcare professionals in early recognition of delirium symptoms. Before implementing such partnership models, it is important to examine the effectiveness of educating family caregivers about delirium.

Aims: To examine whether providing education on delirium to family caregivers improved their knowledge, emotional state, or response in reducing the incidence of delirium in older adults. 
Methods: For this systematic review, we conducted literature searches in CINAHL, Cochrane Library, Medline, PsycINFO, Web of Science, Social Sciences in ProQuest, Dissertations and Theses, and the Virginia Henderson Global Nursing eRepository for studies published in the English language between January 2000 and June 2015. Criteria for inclusion were: (a) primary focus on educating family caregivers for older adults about delirium; (b) use of experimental, quasi-experimental, or comparative design; (c) measured family caregiver outcomes of delirium knowledge, emotional state, or response in reducing delirium incidence in older adults; and (d) published in the English language. Articles were appraised using Melnyk's rapid critical appraisal guides.

Results: Seven studies met the review criteria. Four studies found that family caregivers' delirium knowledge increased; two noted that delirium incidence in older adults declined; and one study reported less distress following receipt of education.

Linking Evidence to Action: Providing family caregivers with information about delirium can be beneficial for both family caregivers and older adults. However, rigorous evaluation of education programs for family caregivers about delirium is needed.

Keywords: family caregivers; delirium; educational intervention; older adults

\section{Introduction}

Delirium is a common, serious problem in older adults. It occurs in up to $64 \%$ of hospitalized older adults and also has been observed in as many as $85 \%$ of those receiving palliative care (Greaves, Vojkovic, Nikoletti, White, \& Yuen, 2008; Inouye, Westendorp, \& Saczynski, 2014). In addition, delirium rates as high as 39\% have been reported in community-dwelling older adults (Mathillas, Olofsson, Lovheim, \& Gustafson, 2013).

Delirium is characterized by sudden onset of confusion, inattention, perceptual disturbance, and illogical or incoherent speech. Older adults who have delirium may fluctuate between hyperactive states with symptoms of agitation or hallucinations and hypoactive states with symptoms of excessive drowsiness or lethargy (Leslie \& Inouye, 2011; Sykes, 2012). Delirium places older adults at an increased risk for falls, prolonged hospital stays, nursing home placement, and a cascade of functional decline. The duration of delirium is associated with these negative outcomes and with

Worldviews on Evidence-Based Nursing, Vol. 13, No. 3 (June 2016): pg. 232-240. DOI. This article is @ Wiley and permission has been granted for this version to appear in e-Publications@Marquette. Wiley does not grant permission for this article to be further copied/distributed or hosted elsewhere without the express permission from Wiley. 
increased mortality (Dasgupta \& Brymer, 2014; Rudolph \& Marcantonio, 2011; Saczynski et al., 2012).

Multiple factors cause or contribute to delirium. Some of these factors include infection, adverse reaction to medications, hypoxia, uncontrolled pain, dehydration, hypoglycemia, electrolyte imbalance, and environmental factors such as use of physical restraints, poor vision, or hearing (American Geriatrics Society Expert Panel on Postoperative Delirium in Older Adults, 2015; Meier, 2012). Unlike dementia, delirium is often reversible when recognized early and the underlying cause is treated. However, healthcare providers who are unfamiliar with the older adult's cognitive baseline often fail to recognize delirium symptoms (Boustani et al., 2010; Greer et al., 2011). Family caregivers, who are familiar with the older adult's usual behaviors, are likely partners in early recognition of delirium. However, family caregivers might attribute delirium symptoms to normal aging or dementia (Bull, 2011; Bull, Boaz, \& Sjostedt, 2014; Toye, Matthews, Hill, \& Maher, 2014).

The findings of descriptive studies indicate that family caregivers experience anxiety, fear, and distress when faced with older adults who have delirium symptoms (Bruera et al., 2009; Toye et al., 2014). Previous reviews support these statements and suggest that family caregivers might benefit from education about delirium (Carbone \& Gugliucci, 2015; Halloway, 2014). However, literature reviews did not specifically address the effectiveness of educating family caregivers about delirium symptoms on outcomes for either family caregivers or older adults. This prompted us to examine whether providing education on delirium to family caregivers improved their knowledge, emotional state, or response in reducing the incidence of delirium in older adults. Specific emotional states of interest included distress and anxiety levels because these were noted in findings of qualitative studies. One might assume that an education intervention that provided information about what to expect might improve family caregivers' emotional state and when information about strategies to prevent delirium are included it might lead to application of knowledge and thereby reduce delirium incidence in older adults (Otani et al. 2014). Examining the evidence for improving outcomes following the receipt of education about delirium is an

Worldviews on Evidence-Based Nursing, Vol. 13, No. 3 (June 2016): pg. 232-240. DOI. This article is (C Wiley and permission has been granted for this version to appear in e-Publications@Marquette. Wiley does not grant permission for this article to be further copied/distributed or hosted elsewhere without the express permission from Wiley. 
essential antecedent to implementing partnership models in nursing practice.

\section{Methods}

For this systematic review, we conducted literature searches in CINAHL, Cochrane Library, Medline, PsycINFO, Web of Science, and Social Sciences in ProQuest for studies published in the English language between January 2000 and June 2015. We searched for gray literature in Dissertations and Theses and the Virginia Henderson Global Nursing eRepository. Search strategies included a combination of subject headings and keywords for each concept-delirium, family caregivers, and educational interventions. We reviewed reference lists and articles citing relevant papers and performed similar article searches to identify additional studies not retrieved through initial database searching. A total of 335 records were retrieved, including 121 duplicates. When duplicates were eliminated, the result was 214 unique records. See flow chart in Figure $\underline{1}$. Thirteen non-English language articles were identified in the search prior to application of the English language limit; however, none of these articles met the inclusion criteria. The abstracts of the unique records were reviewed by the authors to ascertain whether they met the following inclusion criteria: (a) primary focus on educating family caregivers for older adults about delirium; (b) use of experimental, quasi-experimental, or comparative design; (c) measured family caregivers outcomes of delirium knowledge, emotional states, or response in reducing delirium incidence for older adults; and (d) published in the English language. Studies that did not report on these outcomes were excluded. The articles were independently reviewed by two of the authors using Melnyk's rapid critical appraisal guides (Melnyk \& Fine-Overholt, 2015). The criteria on the appraisal guides included key elements such as methodological quality, level of evidence, outcomes measured, sampling approach, findings, statistical and clinical significance, and usefulness of the findings for practice and further research. In synthesizing the findings, articles were grouped by level of evidence and outcomes measured.

Worldviews on Evidence-Based Nursing, Vol. 13, No. 3 (June 2016): pg. 232-240. DOI. This article is (C) Wiley and permission has been granted for this version to appear in e-Publications@Marquette. Wiley does not grant permission for this article to be further copied/distributed or hosted elsewhere without the express permission from Wiley. 
NOT THE PUBLISHED VERSION; this is the author's final, peer-reviewed manuscript. The published version may be accessed by following the link in the citation at the bottom of the page.

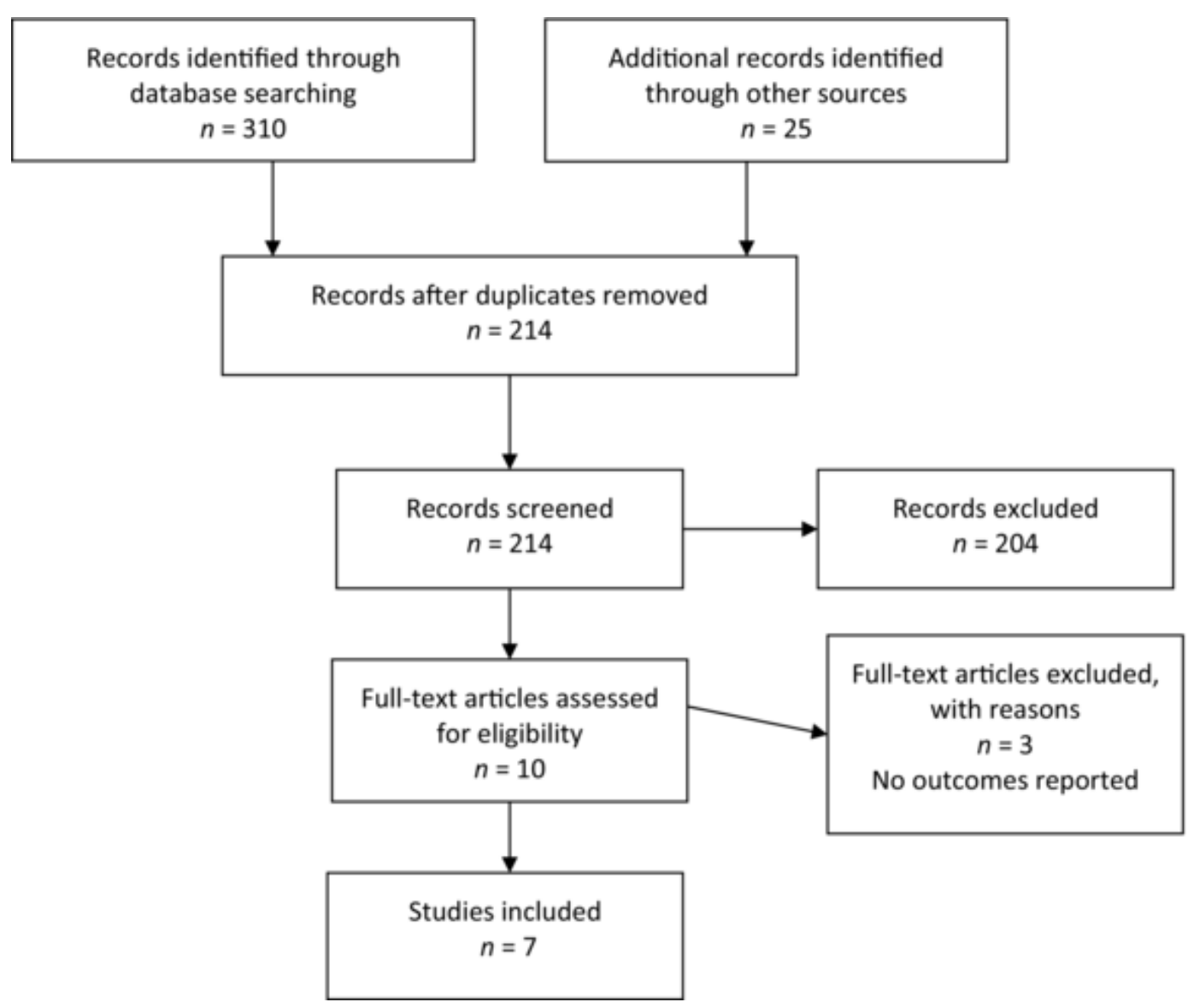

Figure 1. Flow diagram of articles records retrieved.

\section{Findings}

Seven articles met the inclusion criteria and are summarized in Table $\underline{1}$. None of the articles were systematic reviews of randomized controlled trials, Level I, which are considered the highest level of evidence (Melnyk \& Fine-Overholt, 2015). One study (Martinez, Tobar, Beddings, Vallejo, \& Fuentes, 2012) used a randomized design (Level II). The focus of the intervention in this study was on providing family caregivers with information about activities to perform while visiting the hospitalized older adult to prevent delirium. Nurses performed daily assessments for delirium using the Confusion Assessment Method (CAM). The results indicated that older adults with family caregivers in the intervention group had significantly fewer cases of delirium than the control group ( $5.6 \%$ vs. $13.3 \%, p=.027)$. As noted in Table $\underline{1}$, two studies were categorized as level III (Gagnon, Allard, Gagnon, 
NOT THE PUBLISHED VERSION; this is the author's final, peer-reviewed manuscript. The published version may be accessed by following the link in the citation at the bottom of the page.

Merette, \& Tardif, 2012; Rosenbloom \& Fick, 2014). In both studies, family caregivers received information about delirium and its symptoms. Gagnon and colleagues (2012) found no significant differences in delirium incidence for the older adults with cancer in the intervention and control groups.

\begin{tabular}{|c|c|c|c|c|c|c|c|}
\hline Citation & Country & $\begin{array}{l}\text { Purpose and } \\
\text { framework }\end{array}$ & Design method & Sample setting & Measurement tools & Data analysis & $\begin{array}{l}\text { Level of evidence and } \\
\text { addresses PICO } \\
\text { question }\end{array}$ \\
\hline $\begin{array}{l}\text { Black et al. } \\
\text { (2011) }\end{array}$ & Ireland & $\begin{array}{l}\text { Framework: Neuman } \\
\text { Systems Model } \\
\text { Purpose: Examine } \\
\text { effects of } \\
\text { nurse-facilitated family } \\
\text { participation in } \\
\text { psychological care on } \\
\text { psychologic recovery } \\
\text { and delirium extent }\end{array}$ & $\begin{array}{l}\text { Comparative time series } \\
\text { Intervention and control } \\
\text { groups }\end{array}$ & $\begin{array}{l}\text { Setting: Inner city public } \\
\text { hospital } \\
\text { Sample: Convenience } \\
\text { sample } N=69 \text { in } \\
\text { intervention and } N=69 \\
\text { in control } \\
\text { Group } \\
\text { Power analysis }(.80) \\
\text { and effect size }(.50) \\
\text { indicated } N=63 \\
\text { needed per group }\end{array}$ & $\begin{array}{l}\text { Severity of illness was } \\
\text { measured with the } \\
\text { IISS-28, which has } \\
\text { been cross-validated } \\
\text { with the TISS } 76 \\
\text { ( } r=.93 \text { ) } \\
\text { Intensive Care Delirium } \\
\text { Screening Checklist } \\
\text { (Cronbach's alpha } \\
\text {.71-.79) } \\
\text { Sickness Impact Profile } \\
\text { - no validity reported } \\
\text { but has been used in } \\
\text { studies on critical care }\end{array}$ & $\begin{array}{l}\text { Mean delinium scores } \\
\text { between groups was not } \\
\text { statistically significant } \\
\text { Older adults with family } \\
\text { caregivers in the } \\
\text { intervention group had } \\
\text { fewer positive delinum } \\
\text { scores ( } 29 \% \text { vs. } 77 \% \text { ) } \\
\text { than comparison group }\end{array}$ & $\begin{array}{l}\text { Level IV } \\
\text { Addresses PICO } \\
\text { question partially - in } \\
\text { older adults fewer cases } \\
\text { of delirium were } \\
\text { reported though the } \\
\text { results were not } \\
\text { statistically significant. } \\
\text { Family caregiver } \\
\text { knowledge and/or } \\
\text { outcomes was not } \\
\text { addressed }\end{array}$ \\
\hline $\begin{array}{l}\text { Gagnon et al. } \\
(2002)\end{array}$ & Canada & $\begin{array}{l}\text { Framework: None } \\
\text { Purpose: Develop a } \\
\text { psychoeducational } \\
\text { intervention framework, } \\
\text { a brochure to be used } \\
\text { for the intervention, } \\
\text { assess the } \\
\text { intervention's effects on } \\
\text { family and professional } \\
\text { caregivers }\end{array}$ & $\begin{array}{l}\text { Three-phase } \\
\text { study-phase } 3 \text { was } \\
\text { nonrandomized } \\
\text { comparative groups } \\
\text { Phases } 1 \text { and } 2 \\
\text { descriptive to provide } \\
\text { information for } \\
\text { developing intervention }\end{array}$ & $\begin{array}{l}\text { Setting: Terminal } \\
\text { cancer care center } \\
\text { Sample: Phase I- } 21 \mathrm{FC} \\
\text { interviewed over } 2 \\
\text { months for } \\
\text { psychoeducational } \\
\text { intervention } \\
\text { development Phase II- } \\
20 \mathrm{FC} \text { interview for } \\
\text { brochure development } \\
\text { Phase III - Consecutive } \\
\text { sampling of FC. } \\
\text { Intervention group = } \\
58 \text {, comparison group } \\
=66 \mathrm{FC}\end{array}$ & $\begin{array}{l}\text { Measurement outcome: } \\
\text { Family caregiver } \\
\text { knowledge of delirium } \\
\text { Confusion Rating Scale } \\
\text { (Maison Michel-Sarrazin } \\
\text { in-house instrument) } \\
\text { No validity and } \\
\text { reliability of tools } \\
\text { reported }\end{array}$ & $\begin{array}{l}\text { Phase III - Statistically } \\
\text { significant differences } \\
\text { were reported for } \\
\text { Knowledge of Delirium: } \\
\text { frequency of delirium } \\
(p=.038) \text {; causes of } \\
\text { delirium }(p=.032) ; \\
\text { Perceived competence: } \\
\text { Adequate knowledge for } \\
\text { decisions ( } p=.006) ; \\
\text { Attitudes: Information } \\
\text { should be given to all FC } \\
(p=.009)\end{array}$ & $\begin{array}{l}\text { Level III } \\
\text { Partially addressed } \\
\text { PICO question - family } \\
\text { caregiver education had } \\
\text { no effect on the delirium } \\
\text { incidence rate or } \\
\text { severity of cases of } \\
\text { delirium }\end{array}$ \\
\hline $\begin{array}{l}\text { Gagnon, Allard, } \\
\text { Gagnon, } \\
\text { Merette, \& } \\
\text { Tardif (2012) }\end{array}$ & Canada & $\begin{array}{l}\text { Framework: None } \\
\text { Purpose: Tested the } \\
\text { effectiveness of a } \\
\text { multicomponent } \\
\text { intervention to reduce } \\
\text { the incidence and } \\
\text { severity of delinum }\end{array}$ & $\begin{array}{l}\text { Nonrandomized design } \\
\text { Measured delirium } \\
\text { incidence in the older } \\
\text { adults with cancer } \\
\text { Family members were } \\
\text { educated about delirium } \\
\text { and symptoms using a } \\
\text { developed procedure } \\
\text { not described }\end{array}$ & $\begin{array}{l}\text { Setting: Hospice and } \\
\text { palliative care facilities } \\
\text { Sample: Intervention } \\
\text { group }(N=674) \text {, } \\
\text { comparison group } \\
(N=842)\end{array}$ & $\begin{array}{l}\text { Confusion Rating Scale } \\
\text { - validity and reliability } \\
\text { not reported }\end{array}$ & $\begin{array}{l}\text { No statistically } \\
\text { significant differences } \\
\text { between the } \\
\text { intervention and control } \\
\text { groups }\end{array}$ & $\begin{array}{l}\text { Level III } \\
\text { Partially addressed } \\
\text { PICO question - family } \\
\text { caregiver education had } \\
\text { no effect on the delirium } \\
\text { incidence rate or } \\
\text { severity of cases of } \\
\text { delirium }\end{array}$ \\
\hline
\end{tabular}

Worldviews on Evidence-Based Nursing, Vol. 13, No. 3 (June 2016): pg. 232-240. DOI. This article is (C Wiley and permission has been granted for this version to appear in e-Publications@Marquette. Wiley does not grant permission for this article to be further copied/distributed or hosted elsewhere without the express permission from Wiley. 
NOT THE PUBLISHED VERSION; this is the author's final, peer-reviewed manuscript. The published version may be accessed by following the link in the citation at the bottom of the page.

\begin{tabular}{|c|c|c|c|c|c|c|c|}
\hline Citation & Country & $\begin{array}{l}\text { Purpose and } \\
\text { framework }\end{array}$ & Design method & Sample setting & Measurement tools & Data analysis & $\begin{array}{l}\text { Level of evidence and } \\
\text { addresses PICO } \\
\text { question }\end{array}$ \\
\hline $\begin{array}{l}\text { Keyser et al. } \\
\text { (2012) }\end{array}$ & Canada & $\begin{array}{l}\text { Framework: Knowledge } \\
\text { to Action process } \\
\text { (clarifies language } \\
\text { translation) } \\
\text { Purpose: Examine if } \\
\text { knowledge translation } \\
\text { product for families of } \\
\text { community-dwelling } \\
\text { older adulls would } \\
\text { increase knowledge } \\
\text { related to prevention } \\
\text { and identification of } \\
\text { delinum }\end{array}$ & $\begin{array}{l}\text { Design: Pre-post (no } \\
\text { control group) } \\
\text { Four-phases - } \\
\text { I. Focus groups } \\
\text { II. Education } \\
\text { sessions with } \\
\text { families of } \\
\text { community- } \\
\text { dwelling older } \\
\text { adults } \\
\text { III. Semistructured } \\
\text { telephone or } \\
\text { e-mail interview } \\
\text { NV. Intervention- } \\
\text { seven group } \\
\text { educational } \\
\text { sessions held } \\
\text { with } 16 \\
\text { participants }\end{array}$ & $\begin{array}{l}\text { Setting: Community } \\
\text { sample: } N=11 \\
\text { completed; } 25 \\
\text { consented } \\
\text { family caregivers for } \\
\text { community-dwelling } \\
\text { older adults }\end{array}$ & $\begin{array}{l}\text { Phase II Education } \\
\text { Session Package- } \\
\text { consent forms, pre-and } \\
\text { post test, questionnaire, } \\
\text { reference card, two } \\
\text { pamphlets on presented } \\
\text { material Vancouver } \\
\text { Island Health Authority } \\
\text { resources. Validity and } \\
\text { reliability of tools not } \\
\text { reported }\end{array}$ & $\begin{array}{l}\text { Statistically significant } \\
\text { increase in median } \\
\text { knowledge of delirium } \\
\text { score }(W=0, p=.05)\end{array}$ & $\begin{array}{l}\text { Level IV } \\
\text { Partially addresses } \\
\text { PICO - improved } \\
\text { outcomes for family } \\
\text { caregiver knowledge of } \\
\text { delinum. Effects on } \\
\text { delinum in older adults } \\
\text { not addressed }\end{array}$ \\
\hline $\begin{array}{l}\text { Martinez et al. } \\
\text { (2012) }\end{array}$ & Chile & $\begin{array}{l}\text { Framework: None } \\
\text { Purpose: Determine if a } \\
\text { nonpharmacological } \\
\text { intervention about } \\
\text { delirium given to } \mathrm{FC} \\
\text { could reduce the } \\
\text { incidence of delirium } \\
\text { during hospitalization }\end{array}$ & $\begin{array}{l}\text { Design: Randomized } \\
\text { Methods: } \\
\text { Nonpharmacological } \\
\text { intervention included six } \\
\text { elements: (a) Education } \\
\text { about acute confusion } \\
\text { syndromes, (b) } \\
\text { provision of a } \\
\text { clock/calendar, (c) } \\
\text { avoiding sensory } \\
\text { deprivation, (d) } \\
\text { presence of familiar } \\
\text { objects, (e) } \\
\text { reorientation, and (f) } \\
\text { extended visitation }\end{array}$ & $\begin{array}{l}\text { Setting: Internal } \\
\text { medicine ward of a } \\
\text { naval hospital } \\
\text { Sample: Enrolled } \\
\text { intervention group } \\
N=144 \text {, control group } \\
N=143 \text {. } 13 \text { were lost to } \\
\text { follow-up ( } 4 \text { in } \\
\text { treatment group, } 9 \text { in } \\
\text { control group) }\end{array}$ & $\begin{array}{l}\text { CAM - patients were } \\
\text { assessed daily for } \\
\text { delirium symptoms }\end{array}$ & $\begin{array}{l}\text { Statistically significant } \\
\text { differences in the } \\
\text { frequency of delirium } \\
\text { cases between groups } \\
(5.6 \% \text { vs. } 13.3 \% \\
\text { Cl.19-92, } \\
(.92) .027)\end{array}$ & $\begin{array}{l}\text { Level II } \\
\text { Partially addresses } \\
\text { PICO - outcomes were } \\
\text { improved for older } \\
\text { adults with family } \\
\text { caregivers in } \\
\text { intervention group }\end{array}$ \\
\hline
\end{tabular}

\begin{tabular}{|c|c|c|c|c|c|c|c|}
\hline Citation & Country & $\begin{array}{l}\text { Purpose and } \\
\text { framework }\end{array}$ & Design method & Sample setting & Measurement tools & Data analysis & $\begin{array}{l}\text { Level of evidence and } \\
\text { addresses PICO } \\
\text { question }\end{array}$ \\
\hline $\begin{array}{l}\text { Rosenbloom and } \\
\text { Fick (2014) }\end{array}$ & United States & $\begin{array}{l}\text { Framework: None } \\
\text { Purpose: Feasiblity } \\
\text { study to pilot } \\
\text { intervention }\end{array}$ & $\begin{array}{l}\text { Quasi-experimental } \\
\text { pretest-posttest } \\
\text { Intervention: NFCPM } \\
\text { Intervention, a } \\
\text { three-component } \\
\text { intervention consisting } \\
\text { of delirium education, a } \\
\text { nurse/FC partnership } \\
\text { module, and Unit Nurse } \\
\text { Champion }\end{array}$ & $\begin{array}{l}\text { Setting: } 2 \text { acute care } \\
\text { academic medical } \\
\text { centers in Boston, MA, } \\
\text { USA. Sample: Triad } \\
\text { groups of an older } \\
\text { adult, FC \& staff nurse. } \\
\text { Intervention group - } \\
N=14 \text { triads } \\
\text { Control group - } N=14 \\
\text { triads }\end{array}$ & $\begin{array}{l}\text { Delirium knowledge was } \\
\text { measured using } 3 \\
\text { instruments: Knowledge } \\
\text { of Delirium } \\
\text { Questionnaire, case } \\
\text { vignettes, Expectations } \\
\text { Regarding Aging Scale. } \\
\text { Attitudes toward } \\
\text { partnership was } \\
\text { measured with an } \\
\text { adapted version of the } \\
\text { Family-Centered Care } \\
\text { Survey Satisfaction with } \\
\text { the NFCPM was } \\
\text { examined using four } \\
\text { open-ended questions } \\
\text { in in-person interviews } \\
\text { of staff nurses and by } \\
\text { phone calls to FC }\end{array}$ & $\begin{array}{l}\text { Statistically significant } \\
\text { improvement in } \\
\text { knowledge of delirium } \\
(p=.02) \\
\text { Family caregivers } \\
\text { reported satisfaction } \\
\text { with the intervention }\end{array}$ & $\begin{array}{l}\text { Level III } \\
\text { Partially addresses } \\
\text { PICO - Improved family } \\
\text { caregiver knowledge } \\
\text { results in improved } \\
\text { family caregiver } \\
\text { outcomes }\end{array}$ \\
\hline $\begin{array}{l}\text { Otani et al. } \\
\text { (2014) }\end{array}$ & Japan & $\begin{array}{l}\text { Framework: None } \\
\text { Purpose: Assess the } \\
\text { effects of a } \\
\text { leaflet based } \\
\text { intervention on family } \\
\text { perceived distress, the } \\
\text { need for improvements } \\
\text { in professional care for } \\
\text { delinum, and family } \\
\text { knowledge about the } \\
\text { causes of delirium }\end{array}$ & $\begin{array}{l}\text { Quasi-Experimental, } \\
\text { with a historical control } \\
\text { with family caregiver for } \\
\text { EOL patients with } \\
\text { cancer. } \\
\text { Method: Clinicians used } \\
\text { leaflets about delirium } \\
\text { to teach family } \\
\text { caregivers about causes } \\
\text { and implications of } \\
\text { delirium in cancer } \\
\text { patients at EOL } \\
\text { Healthcare } \\
\text { professionals viewed } \\
\text { education video on } \\
\text { delirium in half-day } \\
\text { workshop and received } \\
\text { instructions on use of } \\
\text { leaflet }\end{array}$ & $\begin{array}{l}N=113 \text { intervention } \\
N=242 \text { historical } \\
\text { control } 77 \% \text { response } \\
\text { rate }\end{array}$ & $\begin{array}{l}\text { No formal validation of } \\
\text { delirium knowledge } \\
\text { assessment instrument } \\
\text { No validity and } \\
\text { reliability of tools } \\
\text { reported }\end{array}$ & $\begin{array}{l}\text { Median interval from } \\
\text { patient death to } \\
\text { completing survey } \\
\text { significantly shorter in } \\
\text { intervention group } \\
\text { ( } 9 \text { vs. } 11 \text { months) No } \\
\text { group differences } \\
\text { reported in perceived } \\
\text { distress ( } M 3.6 \text { and } 3.5, \\
\text { respectively) or in need } \\
\text { for improvements in } \\
\text { professional care } \\
\text { Statisticallly significantly } \\
\text { higher scores for } \\
\text { intervention group on } \\
\text { delinum knowledge for } \\
\text { two causes of delirium } \\
(p<.001)\end{array}$ & $\begin{array}{l}\text { Level IV } \\
\text { Partially addresses } \\
\text { PICO- family caregiver } \\
\text { knowiledge improved } \\
\text { No difference in distress } \\
\text { scores }\end{array}$ \\
\hline
\end{tabular}

CAM $=$ Confusion Assessment Method; $\mathrm{EOL}=$ end of life; $\mathrm{FC}=$ family caregiver.

Worldviews on Evidence-Based Nursing, Vol. 13, No. 3 (June 2016): pg. 232-240. DOI. This article is (C Wiley and permission has been granted for this version to appear in e-Publications@Marquette. Wiley does not grant permission for this article to be further copied/distributed or hosted elsewhere without the express permission from Wiley. 
In contrast, Rosenbloom and Fick (2014) focused on delirium knowledge rather than delirium incidence. They reported that family caregivers' knowledge of delirium improved significantly following the intervention $(p=.02)$. As noted in Table $\underline{1}$, the remaining four studies were all level IV, case-control, and cohort studies. Three of the studies (Gagnon et al., 2002; Keyser, Buchanan, \& Edge, 2012; and Otani et al., 2014) measured the outcome, family caregiver delirium knowledge. All of these studies reported that family caregiver knowledge of delirium increased postintervention; Keyser and colleagues reported a statistically significant increase in the median knowledge score $(p=.05)$. Only the study by Otani and colleagues (2014) measured family caregiver distress in addition to delirium knowledge. Family caregivers in the intervention group reported less distress than those in the control group. The fourth level IV study (Black, Boore, \& Parahoo, 2011) focused on decreased delirium incidence and found that the older adults who had family caregivers in the intervention group had fewer positive delirium scores than the comparison group ( $29 \%$ vs. $77 \%$ ). However, there was no statistically significant difference in the mean delirium scores of the intervention and control groups.

These studies were conducted in a variety of settings. Three of the studies were conducted in Canada (Gagnon et al., 2002, 2012; Keyser et al., 2012), one in Chile (Martinez et al., 2012), one in the United States (Rosenbloom \& Fick, 2014), one in Ireland (Black, Boore, \& Parahoo, 2011), and one in Japan (Otani et al., 2014). Three of the samples comprised family caregivers for terminally ill patients with cancer receiving end-of-life care. Three studies obtained samples from hospitalized older adults; one of these was from an intensive care unit. Only one Canadian study obtained a sample of family caregivers for community-dwelling older adults (Keyser et al., 2012). All of the studies used nonprobability samples. Sample sizes ranged from 11 (Keyser et al., 2012) to 1,516 (Gagnon et al., 2012). One study reported sample power to detect difference as .80 with an effect size of .50 (Black et al., 2011). Only the study by Martinez and colleagues (2012) employed random assignment to the intervention and control groups.

Only two studies utilized a conceptual framework. Keyser and colleagues (2012) used the Knowledge to Action framework to develop

Worldviews on Evidence-Based Nursing, Vol. 13, No. 3 (June 2016): pg. 232-240. DOI. This article is @ Wiley and permission has been granted for this version to appear in e-Publications@ Marquette. Wiley does not grant permission for this article to be further copied/distributed or hosted elsewhere without the express permission from Wiley. 
the education sessions for family caregivers of community-dwelling older adults. Using this framework, the researchers initially conducted focus groups with family caregivers to identify their need for information about delirium. Black and colleagues (2010) used the Neuman Systems Model to guide the study and the nurse-facilitated family participation in psychological care intervention. Use of a conceptual framework to guide the intervention in these studies strengthened the evidence for practice and also enhanced the reproducibility with other samples and across other settings (Fawcett \& Garity, 2009).

In summary, the key outcomes measured in these studies of family caregiver education included delirium knowledge, improved emotional state (specifically, less distress), and reduced delirium incidence in the older adult. Four studies reported family caregiver knowledge of delirium increased; two found the delirium incidence in older adults decreased; and one reported less distress in the family caregivers in the intervention group. Although none of the studies measured all three outcomes, each of the studies was well designed for the respective level of evidence. Random assignment to control groups might not have been feasible in settings that used one clinical site because of potential for contamination of data if family caregivers interacted with each other. All of the studies that measured delirium incidence used valid, reliable instruments. Reports of increased delirium knowledge following receipt of education were consistent across studies and levels of evidence. However, the investigators did not provide information on the psychometric properties of the delirium knowledge and distress instruments. This might reflect the state of the science regarding these instruments at the time the studies were conducted. These studies provide a solid foundation for future studies that evaluate effectiveness of educating family caregivers about delirium. As noted previously, the studies were well designed and used valid, reliable instruments to measure delirium incidence. However, future studies using designs that include control groups are needed.

\section{Discussion}

Providing education to family caregivers about delirium has potential benefits for both the older adult and the family caregiver.

Worldviews on Evidence-Based Nursing, Vol. 13, No. 3 (June 2016): pg. 232-240. DOI. This article is (C Wiley and permission has been granted for this version to appear in e-Publications@Marquette. Wiley does not grant permission for this article to be further copied/distributed or hosted elsewhere without the express permission from Wiley. 
Alleviating family caregiver distress would be an important outcome in end of life care as it might enable family members to be present with the older adult and provide care. Of the three studies conducted with family caregivers of terminally ill patients, only Otani and colleagues (2014) measured family caregiver distress. It is also important to consider timing for obtaining these data. In the study conducted by Otani and colleagues (2014), the data on distress were obtained several weeks to months after the patient's death. It is possible that grief and the passage of time might attenuate the family caregiver's recall of any distress related to delirium. Timing is often a delicate balance between obtaining data proximate to the event and being sensitive to anticipatory grief that family caregivers might experience.

Other studies focused on family caregiver response in reducing delirium incidence, clearly a benefit for the older adult. Two studies with family caregivers of hospitalized older adults (Black et al., 2011; Martinez et al., 2012) found fewer cases of delirium in older adults whose family caregivers received education. Although the study by Black and colleagues (2011) did not find statistically significant differences between delirium incidences in older adults whose family members received the education versus those who did not receive education about delirium, it appeared there might be practical significance (Polit \& Beck, 2012, p. 478). The finding of a $29 \%$ occurrence of delirium in the intervention group was considerably lower than the $77 \%$ in the control group. Considering the cascade of functional decline in older adults that often results from delirium, having fewer occurrences of delirium might result in better long-term outcomes for the older adult. It is also important to note that Black and colleagues used a theoretical framework to guide their study. Theory provides evidence for nursing practice, thereby giving additional credence to the study findings and its potential relevance for practice and future research (Fawcett \& Garity, 2009).

In contrast, two other studies that focused on the outcome of delirium incidence with terminally ill cancer patients did not find a reduction in delirium incidence (Gagnon et al., 2002, 2012). Given the physiologic changes that occur at the end of life that can contribute to delirium, one might not expect that providing education would decrease the incidence of delirium. The clinical situation, the nature of the educational intervention, and whether the education could alter the

Worldviews on Evidence-Based Nursing, Vol. 13, No. 3 (June 2016): pg. 232-240. DOI. This article is @ Wiley and permission has been granted for this version to appear in e-Publications@Marquette. Wiley does not grant permission for this article to be further copied/distributed or hosted elsewhere without the express permission from Wiley. 
outcome are important factors to consider in the study design and in evaluating the evidence for practice. Unfortunately, the lack of detail describing the intervention in these studies makes it difficult to evaluate whether the education provided to the family caregiver might have an effect on delirium incidence.

It is important to note that though there were few intervention studies, the perspectives were from five different countries and included acute care, palliative care, and community settings. This suggests that developing best practices in educating family caregivers is of global interest.

Most of the studies that met the criteria for inclusion in this review had methodological flaws; their findings should be viewed with caution. Only the study by Martinez and colleagues (2012) used a randomized design. The lack of randomized designs in other studies makes it difficult to ascertain whether the results could be attributed to the intervention or to a confounding variable.

On the positive side, the studies that measured delirium incidence in the older adult reported using standardized, valid, reliable tools in assessing for delirium. Despite the methodological flaws in these studies, it is important to note that none of the studies reported any adverse effects of the delirium education on either the family caregiver or the older adult. In fact, Rosenbloom and Fick (2014) found family caregivers reported satisfaction with the intervention. This finding is encouraging given that patient and family teaching is a key nursing role. Although none of the studies measured all three outcomes, the findings highlight the gap in knowledge and the need for further research examining the effectiveness of providing education about delirium to family caregivers.

\section{Limitations}

It is important to note that the articles, theses, and dissertations included in the literature search for this evidence review were limited to those in the English language. Also, the search did not include conference proceedings. Nonetheless, our findings support the need for further research given the limited number of studies in the 15-year period from 2000 to 2015.

Worldviews on Evidence-Based Nursing, Vol. 13, No. 3 (June 2016): pg. 232-240. DOI. This article is (C Wiley and permission has been granted for this version to appear in e-Publications@Marquette. Wiley does not grant permission for this article to be further copied/distributed or hosted elsewhere without the express permission from Wiley. 
NOT THE PUBLISHED VERSION; this is the author's final, peer-reviewed manuscript. The published version may be accessed by following the link in the citation at the bottom of the page.

\section{Conclusions And Recommendations}

The state of the science on the outcomes of educating family caregivers about delirium in older adults is limited. Evaluating the effectiveness of providing family caregivers with education about delirium is a critical and relatively untapped area for research. Previous studies clearly indicate family members were distressed by observing delirium symptoms in their older adult (Bruera et al., 2009; Toye et al., 2014); education could alleviate that distress.

Furthermore, with the duration of delirium recognized as a factor contributing to the cascade of functional decline in older adults (Dasgupta \& Brymer, 2014; Rudolph \& Marcantonio, 2011; Saczynski et al., 2012), family caregivers are potential partners in early recognition of delirium symptoms. Educating family caregivers about delirium, its symptoms and the importance of contacting the older adult's healthcare provider when symptoms are noted has the potential to result in early interventions to ameliorate the delirium. Also, the findings of the study by Martinez and colleagues (2012) indicate that family caregivers have a critical role in preventing delirium in hospitalized older adults. Rosenbloom and Fick (2014) were innovative in their approach to educating both family caregivers and nurses about delirium. This two-pronged approach might be essential in creating effective patient-family-provider partnership models that aim to decrease delirium incidence and duration. From the studies reviewed, one can also conclude that providing education about delirium was not viewed as harmful to either the family caregiver or the older adult.

However, there are several recommendations for future research. First, in building the evidence for best practice in educating family caregivers about delirium, it is essential to provide a sufficiently detailed description of the intervention so that readers can evaluate whether the intervention might logically impact the outcomes measured in the study or be feasible in their setting. The lack of a detailed description of the intervention also makes replication difficult. Describing the conceptual framework used in developing the intervention could facilitate clinicians in reproducing the desired outcomes in their setting. Second, the use of valid, reliable measures of outcomes is essential. Valid, reliable measures currently exist for

Worldviews on Evidence-Based Nursing, Vol. 13, No. 3 (June 2016): pg. 232-240. DOI. This article is (C) Wiley and permission has been granted for this version to appear in e-Publications@ Marquette. Wiley does not grant permission for this article to be further copied/distributed or hosted elsewhere without the express permission from Wiley. 
assessing presence or absence of delirium. However, there are fewer, valid, reliable measures of family caregiver delirium knowledge. This suggests the need to examine psychometric properties of these measures and include information on validity and reliability of the measures in publications. Third, it is important to know whether the family caregiver's increased knowledge results in actions that lead to either prevention of delirium or early interventions for its treatment. Fourth, longitudinal studies might provide evidence to support the effects of family caregiver education on the older adult's functional outcomes following hospitalization. Much work remains to build the evidence on outcomes of providing family caregivers with education about delirium. Future work might also examine best practices in providing family caregivers with education about delirium.

\section{Linking Evidence To Action}

- Providing family caregivers with information about delirium can be beneficial for both family caregiver and older adult.

- Conducting rigorous evaluation of education programs for family caregivers about delirium is needed.

- Preparing nurses and other healthcare professionals to partner with family caregivers in early recognition of delirium symptoms might be necessary step in implementing partnership models.

\section{References}

American Geriatrics Society Expert Panel on Postoperative Delirium in Older Adults. (2015). Postoperative delirium in older adults: Best practice statement from the American Geriatrics Society. Journal of the American College of Surgeons, 220(2), 136-148. Retrieved from http://dx.doi.org/10.1016/j.jamcollsurg.2014.10.019

Black, P., Boore, J. R., \& Parahoo, K. (2011). The effect of nursefacilitated family participation in the psychological care of the critically ill patient. Journal of Advanced Nursing, 67(5), 10911101.

Boustani, M., Baker, M. S., Campbell, N., Munger, S., Hui, S. L., \& Callahan, C. (2010). Impact and recognition of cognitive impairment among hospitalized elders. Journal of Hospital

Worldviews on Evidence-Based Nursing, Vol. 13, No. 3 (June 2016): pg. 232-240. DOI. This article is (C) Wiley and permission has been granted for this version to appear in e-Publications@Marquette. Wiley does not grant permission for this article to be further copied/distributed or hosted elsewhere without the express permission from Wiley. 
Medicine, 5(2), 69-75. Retrived from

http://dx.doi.org/10.1002/jhm.589

Bruera, E., Bush, S., Willey, J., Paraskevopoulos, T., Zhijun, L., Palmer, J., \& Elsayem, A. (2009). Impact of delirium and recall on the level of distress in patients with advanced cancer and their family caregivers. Cancer, 115(9), 2004-2011. Retrieved from http://doi.org/10.1002/cncr.24215

Bull, M. J. (2011). Delirium in older adults attending adult day care. International Journal of Older People Nursing, 6(2), 85-92.

Bull, M. J., Boaz, L., \& Sjostedt, J. (2014). Family caregivers' knowledge of delirium and preferred modalities for receipt of information. Journal of Applied Gerontology. Advance Online Publication. Retrieved from http://doi.org/10.1177/0733464814535484

Carbone, M. K., \& Gugliucci, M. R. (2015). Delirium and the family caregiver: The need for evidence-based education interventions. The Gerontologist, 55(3), 345-352. Retrieved from http://doi.org/10.1093/geront/gnu035

Dasgupta, M., \& Brymer, C. (2014). Prognosis of delirium in hospitalized elderly: Worse than we thought. International Journal of Geriatric Psychiatry, 29(5), 497-505.

Fawcett, J., \& Garity, J. (2009). Evaluating research for evidencebased nursing practice. Philadelphia, PA: F.A. Davis.

Gagnon, P., Charbonneau, C. L., Allard, P., Soulard, C., Dumont, S., \& Fillion, L. (2002). Delirium in advanced cancer: A psychoeducational intervention for family caregivers. Journal of Palliative Care, 18(4), 253-261.

Gagnon, P., Allard, P., Gagnon, B., Merette, C., \& Tardif, F. (2012). Delirium prevention in terminal cancer: Assessment of a multicomponent intervention. Psycho-Oncology, 21(2), 187194. Retrieved from http://doi.org/10.1002/pon.1881

Greaves, J., Vojkovic, S., Nikoletti, S., White, K., \& Yuen, K. (2008). Family caregivers' perceptions and experiences of delirium in patients with advanced cancer. Australian Journal of Cancer Nursing, 9(2), 3-11.

Greer, N., Rossom, R., Anderson, P., MacDonald, R., Tacklind, J., Rutks, I., \& Wilt, T. (2011). Delirium: Screening, prevention and diagnosis. A systematic review of evidence. Washington, DC: Department of Veterans Affairs.

Worldviews on Evidence-Based Nursing, Vol. 13, No. 3 (June 2016): pg. 232-240. DOI. This article is (C Wiley and permission has been granted for this version to appear in e-Publications@Marquette. Wiley does not grant permission for this article to be further copied/distributed or hosted elsewhere without the express permission from Wiley. 
Halloway, S. (2014). A family approach to delirium: A review of the literature. Aging and Mental Health, 18(2), 129-139. Retrieved from http://doi.org/10.1080/13607863.2013.814102

Inouye, S. K., Westendorp, R. G., \& Saczynski, J. S. (2014). Delirium in elderly people. Lancet, 383(9920), 911-922. Retrieved from http://doi.org/10.1016/S0140-6736(13)60688-1

Keyser, S., Buchanan, D., \& Edge, D. (2012). Providing delirium education for family caregivers of older adults. Journal of Gerontological Nursing, 38(8), 24-31.

Leslie, D. L., \& Inouye, S. K. (2011). The importance of delirium: Economic and societal costs. Journal of the American Geriatrics Society, 59(2 Suppl.), S241-S243. Retrieved from http://doi.org/10.1111/j.1532-5415.2011.03671.x

Martinez, F. T., Tobar, C., Beddings, C. I., Vallejo, G., \& Fuentes, P. (2012). Preventing delirium in an acute hospital using a nonpharmacological intervention. Age and Ageing, 41, 629-634.

Mathillas, J., Olofsson, B., Lovheim, H., \& Gustafson, Y. (2013). Thirtyday prevalence of delirium among very old people: $A$ population-based study of very old people living at home and in institutions. Archives of Gerontology and Geriatrics, 57(3), 298304.

Meier, D. E. (2012). Pain as a cause of agitated delirium. Archives of Internal Medicine, 172(15), 1130. Retrieved from http://doi.org/10.1001/archinternmed.2012.2088

Melnyk, B. M., \& Fine-Overholt, E. (2015). Evidence-based practice in nursing and healthcare: A guide to best practice (3rd ed.). Philadelphia, PA: Wolters Kluwer Health.

Otani, H., Morita, T., Satsuki, U., Yamamoto, R., Hirose, H., Matsubara, T., \& Sasaki, K. (2014). Effect of a leaflet-based intervention on family members of terminally ill patients with cancer having delirium: Historical control study. American Journal of Hospice and Palliative Medicine, 31(3), 322-326. Retrieved from http://doi.org/10.1177/1049909113486171

Polit, D. F., \& Beck, C. T. (2012). Nursing research: Generating, and assessing evidence for nursing practice. Philadelphia, PA: Lippincott, Williams \& Wilkins.

Rosenbloom, D. A., \& Fick, D. M. (2014). Nurse/family caregiver intervention for delirium increases knowledge and improves

Worldviews on Evidence-Based Nursing, Vol. 13, No. 3 (June 2016): pg. 232-240. DOI. This article is @ Wiley and permission has been granted for this version to appear in e-Publications@Marquette. Wiley does not grant permission for this article to be further copied/distributed or hosted elsewhere without the express permission from Wiley. 
NOT THE PUBLISHED VERSION; this is the author's final, peer-reviewed manuscript. The published version may be accessed by following the link in the citation at the bottom of the page.

attitudes toward partnership. Geriatric Nursing, 35, 175-181. Retrieved from http://doi.org/10.1016/j.gerinurse.2013.12.004 Rudolph, J., \& Marcantonio, E. R. (2011). Postoperative delirium: Acute change with long-term implications. Anesthesia and Analgesia, 112, 1202-1211. Retrieved from http://doi.org/10.1213/ANE.0b013e3182147f6d

Saczynski, J. S., Marcantonio, E. R., Quach, L., Fong, T. G., Gross, A., Inouye, S. K., \& Jones, R. N. (2012). Cognitive trajectories after postoperative delirium. New England Journal of Medicine, 367(1), 30-39. Retrieved from http://doi.org/10.1056/NEJMoa1112923

Sykes, P. K. (2012). Prevention and management of postoperative delirium among older patients on an orthopedic surgical unit: $A$ best practice implementation project. Journal of Nursing Care Quality, 27(2), 146-153. Retrieved from http://doi.org/10.1097/NCQ.0b013e31823f8573

Toye, C., Matthews, A., Hill, A., \& Maher, S. (2014). Experiences, understanding and support needs of family carers of older patients with delirium: A descriptive mixed methods study in a hospital delirium unit. International Journal of Older People Nursing, 9(3), 200-208.

Worldviews on Evidence-Based Nursing, Vol. 13, No. 3 (June 2016): pg. 232-240. DOI. This article is (C Wiley and permission has been granted for this version to appear in e-Publications@Marquette. Wiley does not grant permission for this article to be further copied/distributed or hosted elsewhere without the express permission from Wiley. 